\title{
PATRIARCHAL RELIGION AS PORTRAYED IN GENESIS 12-501
}

\section{Augustine Pagolu}

Although J. Wellhausen had already rejected the historicity of the patriarchs, and with it their religion, and argued that the patriarchal traditions were retrojections dating from the Monarchical period, A. Alt's essay 'Der Gott der Väter' marked a watershed in the study of patriarchal religion. In this essay he argued both for a patriarchal religion distinct from Mosaic religion and for the possibility of its originating during or at just before the settlement of Israelite clans in Canaan. While many since Wellhausen have continued to argue against the historicity of the patriarchs, a number of scholars, in the light of Ugaritic and other archaeological discoveries, have followed Alt in arguing for a distinct patriarchal religion before the Mosaic period. However, the study of patriarchal religion has chiefly been confined either to the different divine names or to the social and legal practices frequently attested in Genesis. As a result, relatively little attention has been paid to patriarchal religious and cultic practices in Genesis.

This thesis takes its departure from the Hebrew Bible's own testimony that patriarchal religion was distinct from Mosaic religion. In the thesis, this distinctiveness is chiefly sought in patriarchal worship and cultic practices, such as altars, pillars, tithes, vows and ritual purity. These aspects are studied in the light of both second millennium ancient Near Eastern and Israelite (i.e., post-Mosaic) parallels. It is argued that while the worship and cultic practices of the patriarchs

\footnotetext{
${ }^{1}$ Augustine Pagolu, Patriarchal Religion As Portrayed In Genesis 12-50: Comparison With Ancient Near Eastern And Later Israelite Religions (unpublished Ph.D. thesis; the Open University, 1995); supervisor: Dr. G.J. Wenham).
} 
have elements in common with both the ANE and Israel, the portrayal of God as God of the fathers and his covenant with the patriarchs are unique features.

Moreover, the nature of the patriarchs' involvement in their cultic practices bears no comparison to that of the ANE or Israel. The patriarchs are described as engaging in these cultic practices in order to maintain their religious piety. There is a consistent portrayal of these practices as being distinctive to their religion and lifestyle. In the ANE altars were not built by individuals, but were largely restricted to organised or popular cults at sanctuaries where priests presided. Similarly, planting trees or raising pillars in order to worship God is explicitly prohibited in latter Israel, yet the writers of Genesis, in spite of their Yahwistic ethos, portray these patriarchal practices as unexceptionable and even approved by God. Again, prayer, tithing, vow making and purificatory rituals were common in the ANE and Israel, but in the latter they largely took place at sanctuaries with the aid of the priests, and were regulated by detailed legislation. In the patriarchal narratives, by contrast, the patriarchs themselves officiated, and there is no legislation relating to any of these practices.

There thus emerges a pattern peculiar to patriarchal religion. In the ANE and Israel, worship was highly organised with an established cult and cultic personnel and with the occasion, purpose and procedures of sacrifices elaborately prescribed. By contrast, the patriarchal cultic practices were informal, with no fixed cult place or cult personnel and with no prescribed sacrifices or procedures.

Patriarchal altars were usually outside the settled communities and probably distinct from their public shrines. The occasions for their sacrifices were prompted by theophany, relocation, covenant and guidance. Unlike in the ANE and Israel, they had no festivals or sacrifices for healing or for battle. The purpose of patriarchal sacrifice is less clear, though it seems mainly to have been for worship, and occasionally for the fulfilment of vows or for thanksgiving.

Similarly, prayer in the patriarchal narratives occurs in the family and other informal contexts, unlike in the ANE and, to a large extent, Israel. Prayer is preserved entirely as 
conversation between the patriarchs and God. The intercession of Abraham is the most telling example of this. Thus the content, setting and theology of prayer in the patriarchal narratives is distinct from that of both the ANE and Israel. The range of problems for which the ANE and Israel approached the deity are surprisingly lacking in the patriarchal narratives, in that there is no prayer for sin and guilt, oppression by enemies or abandonment by the deity, although the patriarchs experienced all these problems. Another distinctive aspect of patriarchal prayer is the prayer of blessing which is never cultic as in the ANE.

One of the most distinctive features of patriarchal religion is the raising of pillars by Jacob. These pillars are unique in that they signify theophanies, worship and commemoration of God and an establishment of a contractual bond with him. Pillars were strongly condemned in later Israel. In the ANE they are not attested as being raised in response to theophanies but were found only in cultic areas or were promised by the devotees.

The patriarchs' practices of tithes, vow making and purificatory rites were similarly distinct, and compatible only with their lifestyle and worship. The unvowed tithe paid by Abraham to the Canaanite priest-king Melchizedek and the unpaid tithe vowed to God by Jacob were not regular, annual, obligatory tithes as in the ANE and Israel. It is uncertain whether Abraham's tithe reflects his religious beliefs: he was following a custom attested both in the ANE and Israel where a portion of booty was paid to the deity. This single activity does not establish his allegiance to the Canaanite deity El, since his normal pattern of worship involved building altars and calling on the name of Yahweh.

The ideas of purity and defilement attested in the patriarchal narratives are compatible with patriarchal lifestyle and religion, and are unlike those attested in the ANE and Israel. Although death, burial and mourning customs are frequently attested, there is only one possible allusion to uncleanness by death, and that in the Joseph cycle set in Egypt. This idea is given little or no significance, in contrast to its paramount importance in the Priestly system. The only time 
the concepts occur with any religious importance is in the Jacob stories, in ch. 35 . But even here they do not have the same import as in the Priestly texts. Their background is to be sought in the ANE where purification is often called for before approaching a holy place and foreign gods are carefully buried to affirm loyalty to one's own god. That Jacob was following such practice is demonstrated from his own experience at Bethel, in Paddan-aram and at Shechem. Therefore, Jacob's practice is distinct from Israel's. In some aspects it is also distinct from ANE practices, because the place where Jacob went to meet with God had no organised cult or priest. Acting by himself he called for purification, buried the idols and other tokens of foreign gods, and on arrival at the holy place built an altar, offered sacrifices and worshipped God.

Thus the patriarchal religious practices are compatible with their worship pattern and their belief in a family God who went along with them wherever they went. Their worship and religious practices are distinct from both ANE and Israel, although they reflect elements of the latter at several points. The patriarchal religion is family oriented, clan based and compatible with the semi-nomadic lifestyle of the patriarchs. Thus the Genesis account of patriarchal religion is feasible, and not likely to be a product of later imagination. Further, the patriarchs appear not only to be living as aliens in the land but also as aliens to the indigenous cult. Their social and political relations with the native inhabitants were usually harmonious, but only on the basis that they were still aliens. This means that their ethnic difference made them distinct as much as their religious practices. This probably had a large effect on their religious observances. The problem of religious syncretism became an issue only after Israel claimed the land as her own and wanted to become like the native inhabitants, but this does not seem to have been a problem for the patriarchs. Their religion was probably less syncretistic than that of Israel at other periods. 